\title{
Introduction to the special issue on submarine geohazard records and potential seafloor instability
}

\author{
Song-Chuen Chen ${ }^{1, *}$ and Jia-Jyun Dong ${ }^{2}$ \\ ${ }^{1}$ Central Geological Survey, Ministry of Economic Affairs, New Taipei City, Taiwan \\ ${ }^{2}$ Graduate Institute of Applied Geology, National Central University, Taoyuan City, Taiwan
}

Received 21 November 2017, Accepted 27 November 2017

Keywords: Submarine landslide, Kaoping Canyon, Southwest Taiwan, Northeast Taiwan

Citation: Chen, S.-C. and J.-J.Dong, 2018: Introduction to the special issue on submarine geohazard records and potential seafloor instability. Terr. Atmos. Ocean. Sci., 29, 1-6, doi: 10.3319/TAO.2017.11.27.01

Submarine landslides frequently occur in passive continental margins or active margins (Hampton et al. 1996; Wynn et al. 2000; Mienert et al. 2002; Korup et al. 2007; Twichell et al. 2009; Cukur et al. 2016). Submarine landslides have been studied extensively not only for scientific research but also for submarine geohazards. Submarine landslides could jeopardize marine infrastructures, such as offshore drilling platforms or submarine telecommunication cables, and could even trigger disastrous tsunamis (Bondevik et al. 2005; Harbitz et al. 2006; Hornbach et al. 2007, 2008; Hsu et al. 2008; Su et al. 2012; Tappin et al. 2014; Li et al. 2015). For instance, one disastrous tsunami hitting the coastal area of southwestern Taiwan in 1781 or 1782 was reported (Chen 1830; Hsu 1983); the tsunami event was probably generated by submarine landslides in the offshore area of southwestern Taiwan (Li et al. 2015). Moreover, several submarine landslides triggered by the 2006 Pingtung earthquake have induced turbidity currents off southwest Taiwan and destroyed about 14 submarine telecommunication cables off SW Taiwan (Hsu et al. 2008). The area of southwest Taiwan currently has a dense population (more than 3 million people in total), one deep-water Kaohsiung Port, several tanks of liquefied natural gas and a nuclear power plant on the coast (Fig. 1). Numerous submarine telecommunication cables exist off SW Taiwan. If a considerable tsunami event would hit again the costal area of SW Taiwan, the damage could very serious. Likewise, there are two nuclear power plants on the coast of northern Taiwan (Fig. 2), and the population in northern Taiwan has more than 10 million people. Submarine telecommunication cables also exist off northern Taiwan. In any case, it is important to understand the status of seafloor stability in the offshore areas of SW and NE Taiwan. For that, this special

\footnotetext{
* Corresponding author

E-mail:songlin@moeacgs.gov.tw
}

issue of submarine geohazard records and potential seafloor instability is aimed to provide some research results, hoping to have a general reconnaissance of submarine landslide potential off Taiwan.

In the offshore area of SW Taiwan, the deformation front is the main tectonic feature and the Kaoping submarine canyon is the most profound canyon (Fig. 1). The deformation front represents the northward continuation of the Manila Trench, separating the fold-and-thrust structures of the active convergent margin to the east and the horstand-graben structures of the passive South China Sea continental margin to the west. The Kaoping submarine canyon provides a main sediment dispersal system, transporting lots of sediments from land to the offshore area of SW Taiwan (Huh et al. 2009; Yu et al. 2009). Associated with active mud volcanoes, numerous gas emissions are distributed between the Kaoping and Fangliao submarine canyons, while few gas emissions are distributed in the vicinity of the deformation front (Fig. 1). In this special issue, Hsu et al. (2018b) have examined the gas emissions distribution and further evaluated the seafloor stability between the Kaoping and Fangliao canyons area. Chen et al. (2018a) have discovered and delineated a large submarine landslide (named Fangliao Slide) to the west of the Fangliao submarine canyon; they have also discussed the possible mechanisms of the slope failure. Cheng et al. (2018) and Lin et al. (2018) have used ocean bottom seismometer data to study the seismic site response and velocity structures of $\mathrm{P}$ - and $\mathrm{S}$-waves in sedimentary layers, respectively. Su et al. (2018) have used a large amount of cored sediments to characterize the geological and geochemical characters and to study the processes of sedimentation, sediments properties and to discuss the seabed stability off SW Taiwan. Hsu et al. (2018a) have used triaxial tests to obtain the effective strength parameters of the cored sediments taken at a landslide, which occurred in the 2006 Pingtung earthquake.

The southernmost part of the Okinawa Trough back-arc 


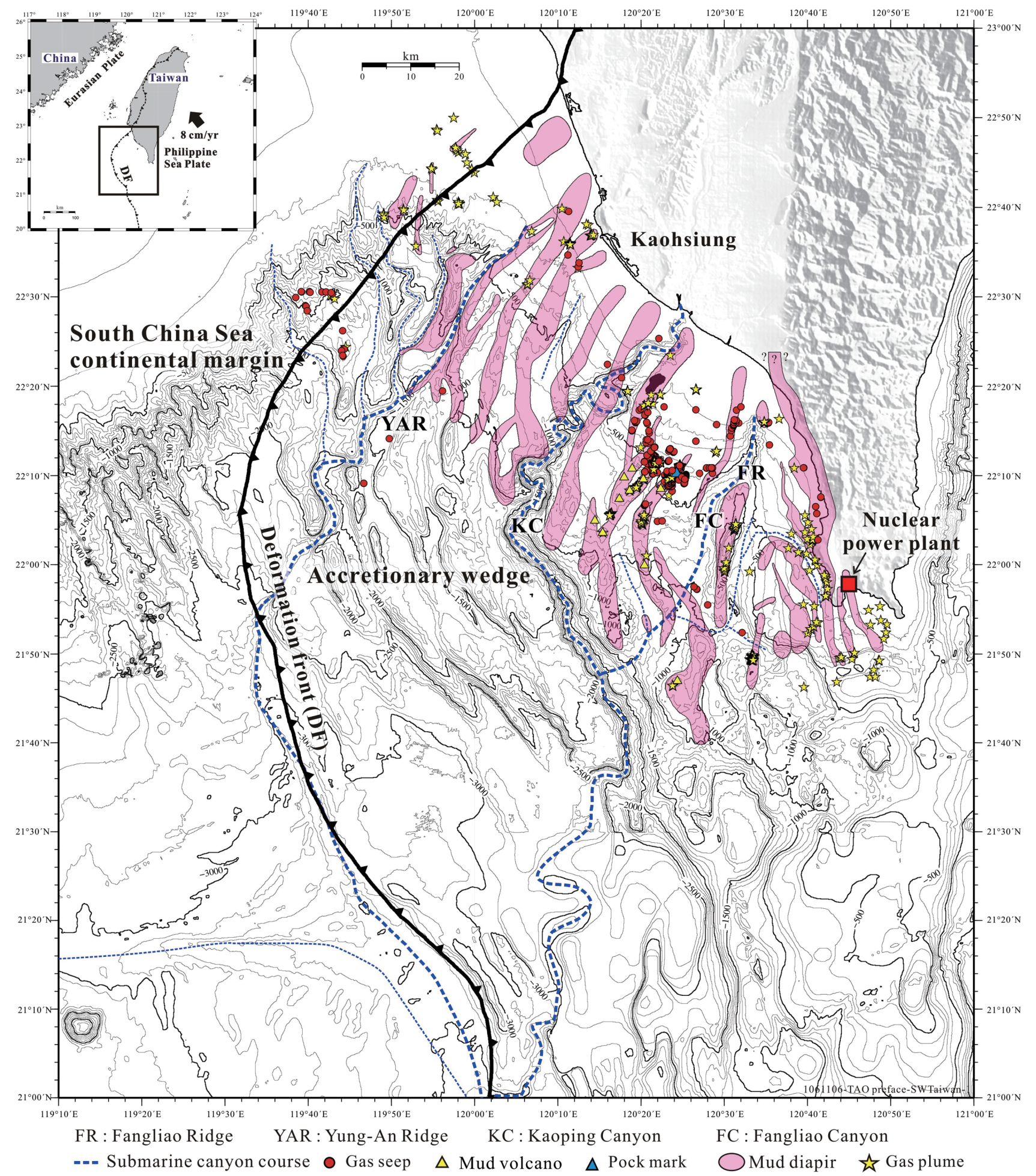

Fig. 1. Bathymetry and related structures off SW Taiwan. The deformation front (DF) separates the active accretionary wedge to the east and the passive South China Sea continental margin to the west. The Kaoping submarine canyon is the most profound canyon off SW Taiwan. 


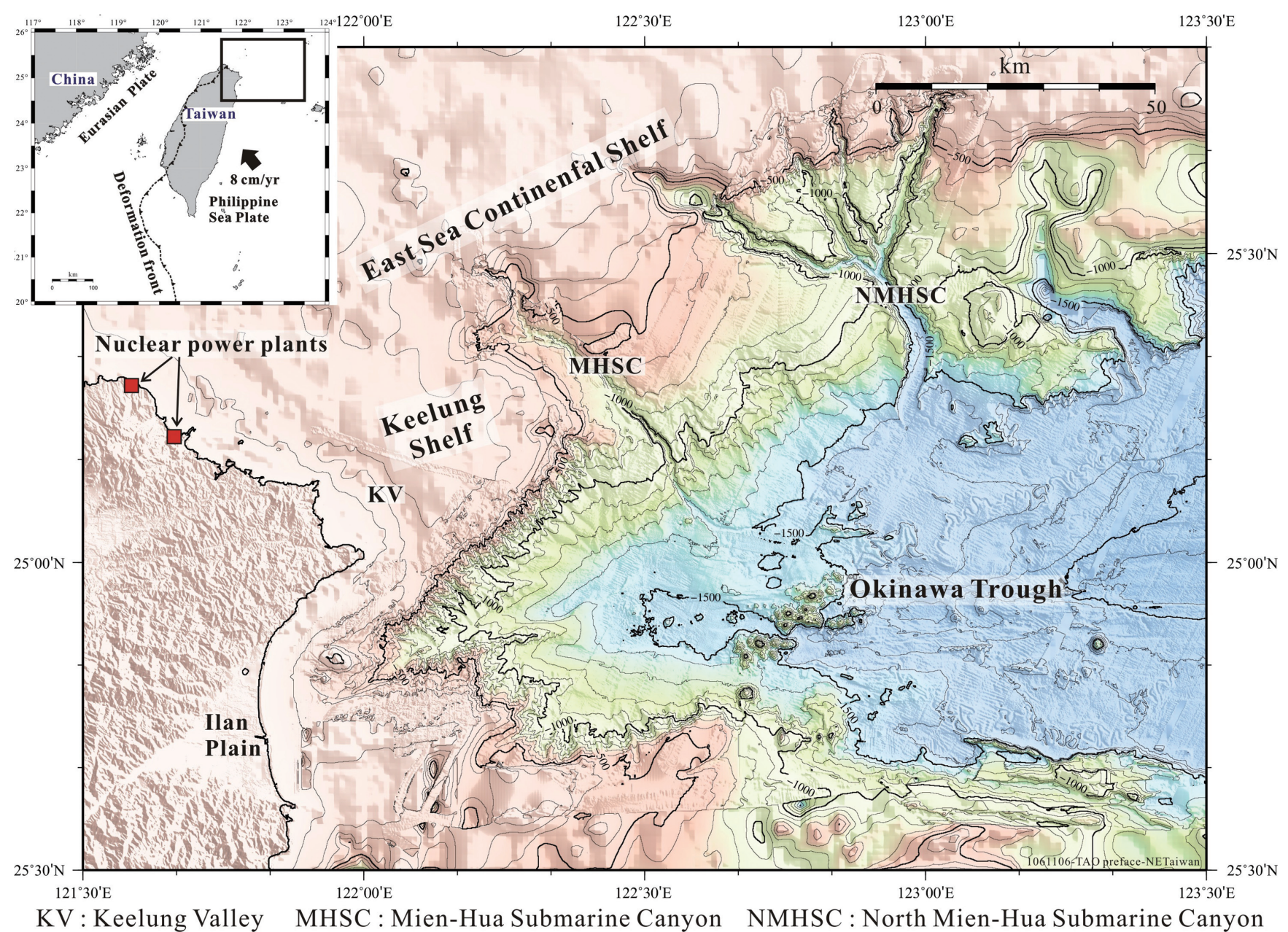

Fig. 2. The topography of the onshore and offshore NE Taiwan. The southern Okinawa Trough back-arc basin, East Sea Continental Shelf and Keelung Shelf are main features off NE Taiwan. The Keelung Valley, Mein-Hua Submarine Canyon (MHSC) and North Mein-Hua Submarine Canyon (NMHSC) are main canyons developed on the continental shelf. The MHSC and NMHSC have incised into shelf more than $500 \mathrm{~m}$.

basin, East Sea Continental Shelf and Keelung Shelf are main topographic units in the offshore area of northern Taiwan (Fig. 2). Developing on the continental shelf the Keelung Valley, Mein-Hua Submarine Canyon (MHSC) and North Mein-Hua Submarine Canyon (NMHSC) are three major submarine canyons off NE Taiwan (Fig. 2). The MHSC and NMHSC have incised deeply the shelf more than $500 \mathrm{~m}$ and formed profound canyons in the continental shelf. Based on the bathymetric map, the Keelung Shelf located between the Keelung Valley and MHSC displays a steep slope angle of $\sim 6^{\circ}$, and the area of between the MHSC and the NMHSC shows a gentle slope angle of $\sim 1.5^{\circ}$. Owing to the slope angles are very different in the two areas, Tsai et al. (2018) have studied and evaluated the seafloor stability of the area.

The marine geological, geophysical and geochemical data shown in the papers of this special issue mainly come from the gas hydrate investigation program (from 2004 to 2015) supported by Central Geological Survey (CGS), Ministry of Economic Affairs, Republic of China (ROC).
Moreover, under the support of National Energy Program of Taiwan, the seafloor stability in the offshore area of SW Taiwan has been further investigated. Gas hydrates are important not only on their energy resource potential but also on their roles as submarine geohazards and their effects on global climate change. Dissociation of the gas hydrates beneath the seafloor may lead to geological hazards such as submarine landslides and tsunamis (McIver 1982), and may enhance global warming and climate change due to the release of methane greenhouse gas to atmosphere. Therefore, this special issue presents new results from the seafloor stability studies in the aforementioned area. A total of eight papers are included in this special issue. They can be divided into four groups: (1) the results of geophysical investigations (Chen et al. 2018a; Cheng et al. 2018; Hsu et al. 2018b; Lin et al. 2018; Tsai et al. 2018), (2) the geological and geochemical investigations (Su et al. 2018), (3) the geotechnical engineering study (Hsu et al. 2018a), and (4) the failure mechanisms of submarine landslide (Chen et al. 
$2018 b)$. They are briefly described in the following.

Hsu et al. (2018b) first systematically summarize the all of the sub-bottom profiler and EK echo sounder data to map the gas emissions distribution off SW Taiwan and obtain the sites of 19 mud volcanoes, 220 gas seeps and 295 gas plumes off SW Taiwan. Their results show that most of gas emissions are located between the Kaoping and Fangliao submarine canyons. Particularly the mud volcanoes are mainly distributed in the area of the Kaoping submarine mud volcanoes group (KASMVG) and few gas emissions are located at deformation front (DF) area. They discussed the difference of mechanisms of gas emissions in the two areas and concluded that the intensive gas expulsions of the KASMVG is ascribed to a deep V-shaped canyon, which has caused a steep bottom simulating reflector (BSR) slope of $\sim 15^{\circ}$ and facilitated the upward free gas migration beneath the BSR and created a cluster of mud volcanoes. On the other hand, the few gas emissions in the DF area is related to a smooth morphology and gentle BSR slope. They also found that large-scale submarine landslides are generally absent owing to the existence of mud diapirs, which could be effectively disturb the seabed morphology. The Fangliao Slide is the largest submarine landslide in the area and is illustrated in Chen et al. (2018a) in this special issue.

Chen et al. (2018a) found the Fangliao Slide in the upper Kaoping Slope off SW Taiwan and discussed the triggering mechanisms of the slide based on MCS profiles and multi-beam bathymetric data. The Fangliao Slide could cover an area of $\sim 15 \mathrm{~km}$ long and $\sim 10 \mathrm{~km}$ wide and a volume of $\sim 26 \mathrm{~km}^{3}$. Their results show that the Fangliao Slide is characterized by a listric bottom with a sliding trend toward south. The Fangliao Slide is bounded by five normal faults and the headwall of the landslide has $\sim 30 \mathrm{~m}$ vertical offset located at the southern flank of a mud diapir. The Fangliao Slide is generally characterized by a relatively smooth bathymetry with a gentle slope between $\sim 1^{\circ}$ and $\sim 2^{\circ}$. They concluded that the initial slope failure was probably linked to a mud diapirism and was probably augmented by the gas hydrate dissociation in the lower portion.

Tsai et al. (2018) have examined the slope stability in the Keelung Shelf off NE Taiwan. They assessed the slope stability between the Keelung Valley and the Mein-Hua Submarine Canyon based on multi-beam bathymetry, multichannel seismic reflection and deep-towed sub-bottom profiler data. They found a dense distribution of active normal faults in the trends of NE-SW or W-E. Those faults show obvious vertical offsets of $5-15 \mathrm{~m}$ on seabed and the eastern portion has slightly larger offsets than in the western portion. They concluded that the submarine landslides in the Keelung Shelf occur gradually from east to west and the overall slope failure is dominated by a spread type landslide.

Cheng et al. (2018) analyzed ocean bottom seismometer (OBS) data acquired in the Yung-An Ridge gas hydrate potential area and studied the velocity structures of $\mathrm{P}$ - and
S-waves in sedimentary layers. Their results showed that the $\mathrm{Vp}$ is about $1.58 \mathrm{~km} \mathrm{~s}^{-1}$ at seafloor and increases with depth to a maximum value of $\sim 2 \mathrm{~km} \mathrm{~s}^{-1}$ at bottom simulating reflector (BSR) but drops to $1.62-1.74 \mathrm{~km} \mathrm{~s}^{-1}$ below the BSR where the presence of free gas in the sedimentary layer. The values of Vs range from $0.3-0.6 \mathrm{~km} \mathrm{~s}^{-1}$. Above the BSR, the western flank of the Yung-An Ridge is characterized by a prominent lateral velocity variation of S-wave. They suggested that the development of thrust faults could result in the slope failure in the area.

Lin et al. (2018) have studied the seismic site response and sedimentary properties by ocean bottom seismometers (OBSs) data acquired in the tectonic settings of the upper Kaoping (Gaoping) Slope and lower Kaoping Slope areas. Based on the recorded earthquakes and ambient noises, they have calculated the horizontal-to-vertical $(\mathrm{H} / \mathrm{V})$ spectral ratios and characterized the local seismic site response and sedimentary properties according to fundamental frequencies. Their results show the maximum $\mathrm{H} / \mathrm{V}$ ratios range from $3.66-9.28 \mathrm{~Hz}$, indicating that fundamental frequencies are dominated by the shallow sediments $(8-39 \mathrm{~m})$. They compared the H/V ratios types of the two tectonic settings and discussed the sediment compositions in the different tectonic settings. They concluded that the existence of positive correlation between the fundamental frequency and bulk density of sediments, which may help design safer submarine infrastructures.

Thick and weakly cemented sedimentary deposit is one of important preconditioning factors for submarine landslides. In order to understand seabed stability, it is important to characterize the sediment source, budget and transportation. Su et al. (2018) have discussed the slope failure based on sub-bottom profiler data and sedimentary cores off SW Taiwan. They pointed out that the flanks of the Gaoping Submarine Canyon (GSC) and Lower Fangliao Basin are two main deposition zones off SW Taiwan. The high bulk density sediments are distributed not only at the shelf and the upper Gaoping Slope but also at the toe of the upper slope. Their paper suggested that the seabed of the northern upper Gaoping Slope area is more stable than the southern upper Gaoping Slope area. They also suggested the retrogressive submarine slumps with possible liquefaction structures in the upper Gaoping Slope.

As the 2006 Pingtung earthquake triggered several submarine landslides, turbidity currents were induced and the submarine telecommunication cables off SW Taiwan were broken (Hsu et al. 2008). However, the mechanical mechanisms of the submarine landslides triggered by 2006 Pingtung earthquake are still poorly understood. It was fortunate to have had two close chirp sonar images before and after the 2006 Pingtung earthquake, thus the morphology and sliding surface was inferred (Hsu et al. 2008). Hsu et al. (2018a) use triaxial tests to obtain the effective strength parameters of the cored sediments based on the chirp sonar 
profile. The effective cohesion and effective friction angle were obtained. In addition, Hsu et al. (2018a) have analyzed the drain and undrain strength parameters on the sliding surface. The back analysis has yielded an undrained strength ratio, which fits well with geotechnical practice.

Inclined seafloor is an important preconditioning factor for submarine landslides (Hampton et al. 1996). Nevertheless, submarine landslides on continental slopes with low gradients were reported worldwide. The mechanisms of submarine landslides occurred at a low slope angle (even less than $1^{\circ}$ ) could be related to gas hydrate dissociation, earthquakes, the presence of weak layers, or the compressibility of sediments (Baraza et al. 1999; Kvalstad et al. 2005; Hornbach et al.2007; Urlaub et al. 2015). Different from the previous studies, Chen et al. (2018b) took into account the frictional heating generated by sliding and proposed another possible mechanism of submarine landslide occurs on gentle slope. They incorporated three mechanisms of thermopressurization weaking, shear dilatancy and thermal softening together to evaluate their contributions on the initiation of landslide on gentle slope. Their simulation results revealed that the frictional heating in the basal shear zone generated by initial sliding could lubricate the landslide motion and facilitate the long distance of submarine landslide.

In summary, this special issue has collected research papers on the potential seafloor instability off SW and NE Taiwan. It not only offers the recent seafloor instability study in the offshore areas of NE and SW Taiwan, but also provides an important background for further the seafloor instability study. The seafloor stability research was rare off Taiwan, we hope this special issue can serve as an important reference to promote more studies on seafloor instability in the future.

Acknowledgements We dedicate this special issue to the Ministry of Science and Technology (MOST) and Central Geological Survey, MOEA (CGS). The MOST financially supported the seafloor instability study and the CGS provided a lot of basic data including geological, geophysical and geochemical data results from 12-years gas hydrate program off SW Taiwan. We are grateful to all the authors and the reviewers, without their efforts would not make this special issue possible. Finally, we would like to thank the Editorin-Chief of Terrestrial, Atmospheric and Oceanic Sciences (TAO), Prof. Shu-Kun Hsu and the Editor in Geology Field of TAO, Prof. Chung-Pai Chang for largely improving the papers in this special issue.

\section{REFERENCES}

Baraza, J., G. Ercilla, and C. H. Nelson, 1999: Potential geologic hazards on the eastern Gulf of Cadiz slope (SW Spain). Mar. Geol., 155, 191-215, doi: 10.1016/ s0025-3227(98)00147-9. [Link]
Bondevik, S., F. Løvholt, C. Harbitz, J. Mangerud, A. Dawson, and J. Inge Svendsen, 2005: The Storegga Slide tsunami-comparing field observations with numerical simulations. Mar. Petrol. Geol., 22, 195-208, doi: 10.1016/j.marpetgeo.2004.10.003. [Link]

Chen, G.-Y., 1830: Taiwan Interview Catalogue, Rep. (in Chinese)

Chen, S.-C., C.-H. Tsai, S.-K. Hsu, Y.-C. Yeh, C.-S. Liu, S.-H. Chung, and C.-Y. Wei, 2018a: Fangliao Slide a large slope failure in the upper Kaoping Slope off southwest Taiwan. Terr. Atmos. Ocean. Sci., 29, $17-$ 30, doi: 10.3319/TAO.2017.06.14.01. [Link]

Chen, W., R. Yang, and H. Hwung, 2018b: Frictional heating lubrication for submarine landslide. Terr. Atmos. Ocean. Sci., 29, 87-103, doi: 10.3319/ TAO.2017.03.22.02. [Link]

Cheng, W.-B., Y.-R. Wu, C.-W. Liang, J.-Y. Lin, and S.K. Hsu, 2018b: Imaging P- and S-wave velocity structures in hydrate bearing sediments along an OBS profile across the Yuan-An Ridge, off southwest Taiwan. Terr. Atmos. Ocean. Sci., 29, 39-50, doi: 10.3319/ TAO.2017.07.04.01. [Link]

Cukur, D., S.-P. Kim, G.-S. Kong, J.-J. Bahk, S. Horozal, I.-K. Um, G.-S. Lee, T.-S. Chang, H.-J. Ha, D. Völker, and J.-K. Kim, 2016: Geophysical evidence and inferred triggering factors of submarine landslides on the western continental margin of the Ulleung Basin, East Sea. Geo-Mar. Lett., 36, 425-444, doi: 10.1007/ s00367-016-0463-5. [Link]

Hampton, M. A., H. J. Lee, and J. Locat, 1996: Submarine landslides. Rev. Geophys., 34, 33-59, doi: 10.1029/95RG03287. [Link]

Harbitz, C. B., F. Lovholt, G. Pedersen, S. Glimsdal, and D. G. Masson, 2006: Mechanisms of tsunami generation by submarine landslides - a short review. Norwegian Journal of Geology, 86, 255-264.

Hornbach, M. J., L. L. Lavier, and C. D. Ruppel, 2007: Triggering mechanism and tsunamogenic potential of the Cape Fear Slide complex, U.S. Atlantic margin. Geochem. Geophys. Geosyst., 8, Q12008, doi: 10.1029/2007GC001722. [Link]

Hornbach, M. J., S. A. Mondzie, N. R. Grindlay, C. Frohlich, and P. Mann, 2008: Did a submarine slide trigger the 1918 Puerto Rico tsunami? Science of Tsunami Hazards, 27, 22-31.

Hsu, H., 1983: Source materials on the history of natural disasters in Ching, Taiwan. Hazards Mitigation S\&T Report, Vol. 72-01, 5-6. (in Chinese)

Hsu, H.-H., J.-J. Dong, S.-K. Hsu, and C.-C. Su, 2018a: Back analysis of an earthquake-triggered submarine landslide near the SW of Xiaoliuqiu. Terr. Atmos. Ocean. Sci., 29, 77-85, doi: 10.3319/TAO.2017.05.08.01. [Link]

Hsu, S.-K., J. Kuo, C.-L. Lo, C.-H. Tsai, W.-B. Doo, C.-Y. 
$\mathrm{Ku}$, and J.-C. Sibuet, 2008: Turbidity currents, submarine landslides and the 2006 Pingtung earthquake off SW Taiwan. Terr. Atmos. Ocean. Sci., 19, 767-772, doi: 10.3319/TAO.2008.19.6.767(PT). [Link]

Hsu, S.-K., S.-S. Lin, S.-Y. Wang, C.-H. Tsai, W.-B. Doo, S.-C. Chen, J.-Y. Lin, Y.-C. Yeh, H.-F. Wang, and C.W. Su, 2018b: Seabed gas emissions and submarine landslides off SW Taiwan. Terr. Atmos. Ocean. Sci., 29, 7-15, doi: 10.3319/TAO.2016.10.04.01. [Link]

Huh, C.-A., H.-L. Lin, S. Lin, and Y.-W. Huang, 2009: Modern accumulation rates and a budget of sediment off the Gaoping (Kaoping) River, SW Taiwan: A tidal and flood dominated depositional environment around a submarine canyon. J. Mar. Syst., 76, 405-416, doi: 10.1016/j.jmarsys.2007.07.009. [Link]

Korup, O., J. J. Clague, R. L. Hermanns, K. Hewitt, A. L. Strom, and J. T. Weidinger, 2007: Giant landslides, topography, and erosion. Earth Planet. Sci. Lett., 261, 578-589, doi: 10.1016/j.eps1.2007.07.025. [Link]

Kvalstad, T. J., L. Andresen, C. F. Forsberg, K. Berg, P. Bryn, and M. Wangen, 2005: The Storegga slide: Evaluation of triggering sources and slide mechanics. Mar. Petrol. Geol., 22, 245-256, doi: 10.1016/j.marpetgeo.2004.10.019. [Link]

Li, L., A. D. Switzer, Y. Wang, R. Weiss, Q. Qiu, C.-H. Chan, and P. Tapponnier, 2015: What caused the mysterious eighteenth century tsunami that struck the southwest Taiwan coast? Geophys. Res. Lett., 42, 8498-8506, doi: 10.1002/2015g1065567. [Link]

Lin, J.-Y., Y.-F. Chen, C.-C. Su, S.-J. Chin, W.-B. Cheng, W.-N.Wu,C.-W.Liang,H.-S.Hsieh, S.-K.Hsu, and Y.C. Lin, 2018: Seismic site response of submarine slope offshore southwestern Taiwan. Terr. Atmos. Ocean. Sci., 29, 51-63, doi: 10.3319/TAO.2017.05.09.01. [Link]

McIver, R.D., 1982: Role of naturally occurring gas hydrates in sediment transport. AAPG Bull., 66, 789-792, doi: 10.1306/03b5a318-16d1-11d7-8645000102c1865d. [Link]

Mienert, J., C. Berndt, J. S. Laberg, and T. O. Vorren, 2002: Slope instability of continental margins. In: Wefer, G., D. Billet, D. Hebbeln, B. B. Jørgensen, M. Schlüter, and T. C. E. Van Weering (Eds.), Ocean Margin Systems, Springer-Verlag, Berlin Heidelberg, 179-193, doi: 10.1007/978-3-662-05127-6_11. [Link]

Su, C.-C., J.-Y. Tseng, H.-H. Hsu, C.-S. Chiang, H.-S. Yu, S. Lin, and J. T. Liu, 2012: Records of submarine natural hazards off SW Taiwan. Geol. Soc. Lond. Spec. Publ., 361, 41-60, doi: 10.1144/SP361.5. [Link]

Su, C.-C., S.-T. Hsu, H.-H. Hsu, J.-Y. Lin, and J.-J. Dong, 2018: Sedimentological characteristics and seafloor failure offshore SW Taiwan. Terr. Atmos. Ocean. Sci., 29, 65-76, doi: 10.3319/TAO.2017.06.21.01. [Link]

Tappin, D. R., S. T. Grilli, J. C. Harris, R. J. Geller, T. Masterlark, J. T. Kirby, F. Shi, G. Ma, K. K. S. Thingbaijam, and P. M. Mai, 2014: Did a submarine landslide contribute to the 2011 Tohoku tsunami? Mar. Geol., 357, 344-361, doi: 10.1016/j.margeo.2014.09.043. [Link]

Tsai, C.-H., C.-L. Huang, S.-K. Hsu, W.-B. Doo, S.-S. Lin, S.-Y. Wang, J.-Y. Lin, and C.-W. Liang, 2018: Active normal faults and submarine landslides in the Keelung Shelf off NE Taiwan. Terr. Atmos. Ocean. Sci., 29, 3138, doi: 10.3319/TAO.2017.07.02.01. [Link]

Twichell, D. C., J. D. Chaytor, U. S. ten Brink, and B. Buczkowski, 2009: Morphology of late Quaternary submarine landslides along the U.S. Atlantic continental margin. Mar. Geol., 264, 4-15, doi: 10.1016/j.margeo.2009.01.009. [Link]

Urlaub, M., P. J. Talling, A. Zervos, and D. Masson, 2015: What causes large submarine landslides on low gradient $\left(<2^{\circ}\right)$ continental slopes with slow $(\sim 0.15 \mathrm{~m} / \mathrm{kyr})$ sediment accumulation? J. Geophys. Res., 120, 67226739, doi: 10.1002/2015jb012347. [Link]

Wynn, R. B., D. G. Masson, D. A. Stow, and P. P. Weaver, 2000: The Northwest African slope apron: A modern analogue for deep-water systems with complex seafloor topography. Mar. Petrol. Geol., 17, 253-265, doi: 10.1016/s0264-8172(99)00014-8. [Link]

Yu,H.-S., C.-S. Chiang, and S.-M. Shen, 2009: Tectonically active sediment dispersal system in SW Taiwan margin with emphasis on the Gaoping (Kaoping) Submarine Canyon. J. Mar. Syst., 76, 369-382, doi: 10.1016/j. jmarsys.2007.07.010. [Link] 